ppi $201502 Z U 4645$

Esta publicación científica en formato digital es continuidad de la revista impresa ISSN-Versión Impresa 0798-1406 / ISSN-Versión on line 2542-3185Depósito legal pp $197402 Z$ U34

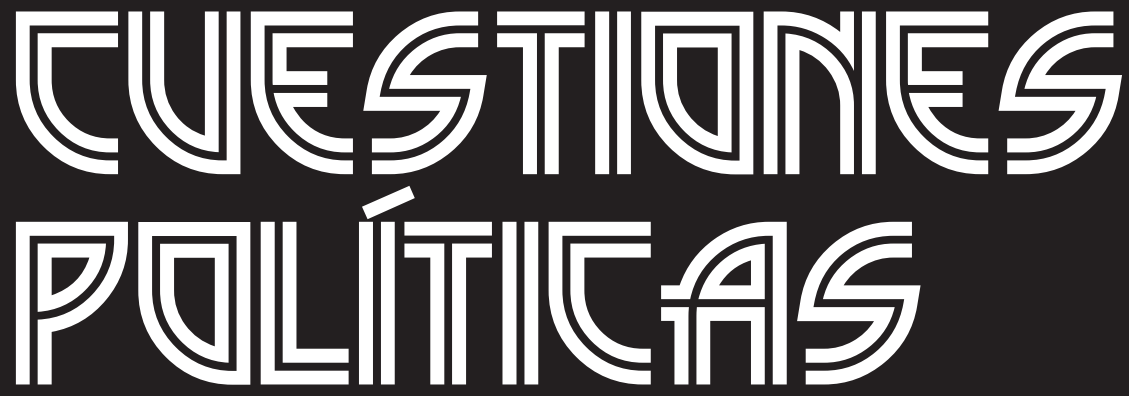

Instituto de Estudios Políticos y Derecho Público "Dr. Humberto J. La Roche" de la Facultad de Ciencias Jurídicas y Políticas de la Universidad del Zulia Maracaibo, Venezuela
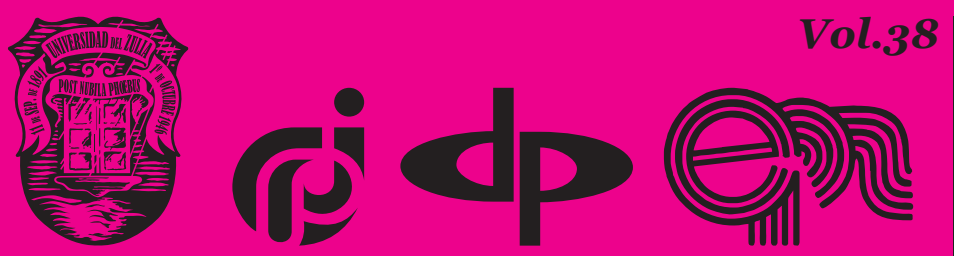

$N^{\circ}$ Especial 1era Parte 2020 


\title{
Social and Legal Healthcare Models and Their Functioning During a Global Crisis
}

\author{
DOI: https://doi.org/10.46398/cuestpol.38e.16
}

\begin{abstract}
Alexandre Anatolievich Mokhov * Yury Alexandrovich Svirin **

Vladimir Aleksandrovich Gureev ***

Vladimir Viktorovich Kulakov ****

Sergej Nikolaevich Shestov ${ }^{* * * * *}$
\end{abstract}

\section{Abstract}

The article analyzes the existing health models in terms of their legal, economic and social effectiveness, innovative potential, as well as in the context of their ability to resist modern threats caused by changes in the environment, ecology, bio-information development and other technologies. The authors used the methods of comparative analysis, synthesis, structural-functional and statistical analysis. Everything indicates the need for a major modernization of existing care models and / or their replacement by new ones that satisfy the basic needs of the majority of society at the current stage of its development. Among the most prominent findings, it is also highlighted that the health insurance model is a creation of the late 19th and early 20th centuries. It was developed and implemented at a time when the economy, society, the social sphere, and technologies were completely different. The 2020 pandemic has revealed the reasons for the unsatisfactory health care work, in a seemingly as prosperous country as the United States, where the largest amount of budget money traditionally goes to health care.

Keywords: Socioeconomic models of health; government regulation of health; health financing; coronavirus infection (COVID-2019); biological security in the new world order.

Kutafin Moscow State Law University, Moscow, Russia. ORCID ID: https://orcid.org/oooo-ooo18811-9329. Email: alexandr.a.mokhov@mail.ru

* All-Russian State University of Justice, Moscow, Russia; Academy of Natural Sciences, Moscow, Russia; Academy of Fundamental Sciences, Moscow, Russia. ORCID ID: https://orcid.org/ooooooo1-7616-2637. Email: yury_svirin@mail.ru

*** All-Russian State University of Justice, Moscow, Russia. ORCID ID: https://orcid.org/oooo-ooo17639-2213. Email: gureev.v.a@bk.ru

*****All-Russian State University of Justice, Moscow, Russia. ORCID ID: https://orcid.org/oooo-ooo17293-4695. Email: kulakov.v.v@list.ru

*****Academy of Labor and Social Relations, Moscow, Russia. ORCID ID: https://orcid.org/oooo-0oo26117-1423. Email: shestoff.sergej@yandex.ru 


\section{Modelos sociales y legales de atención de la salud y su funcionamiento durante una crisis global}

\section{Resumen}

El artículo analiza los modelos de salud existentes en términos de su efectividad legal, económica y social, potencial innovador, así como en el contexto de su capacidad para resistir las amenazas modernas causadas por cambios en el medio ambiente, ecología, desarrollo de bioinformación y otras tecnologías. Los autores utilizaron los métodos de análisis comparativo, síntesis, análisis estructural-funcional y estadístico. Todo indica la necesidad de una importante modernización de los modelos asistenciales existentes y/o su sustitución por otros nuevos que satisfagan las necesidades básicas de la mayoría de la sociedad en la etapa actual de su desarrollo. Entre los hallazgos más prominentes se destaca además que el modelo de seguro de salud es una creación de finales del siglo XIX y principios del XX. Fue desarrollado e implementado en una época en que la economía, la sociedad, el ámbito social y las tecnologías eran completamente diferentes. La pandemia de 2020 ha revelado las razones del trabajo insatisfactorio de la atención médica, en un país aparentemente tan próspero como Estados Unidos, donde la mayor cantidad de dinero del presupuesto tradicionalmente se destina a la atención médica.

Palabras clave: Modelos socioeconómicos de salud; regulación gubernamental de la salud; financiamiento de la salud; infección por coronavirus (COVID-2019); seguridad biológica en el nuevo orden mundial.

\section{Introduction}

Regardless of the characteristics of a particular country or region, the public health system has the following general tasks: improving public health, increasing the duration and quality of life of citizens; increasing the availability and quality of services; ensuring equitable access to health services. For example, in Decree No. 254 of the President of the Russian Federation "On the Healthcare Development Strategy in the Russian Federation for the period until 2025" dated June 6, 2019, attention is drawn to the need for increasing the population, life expectancy, healthy life expectancy, reducing mortality and disability, respecting the rights of citizens in the field of healthcare, and providing state guarantees related to these rights. 


\section{Alexandre Anatolievich Mokhov, Yury Alexandrovich Svirin, Vladimir Aleksandrovich Gureev, Vladimir Viktorovich Kulakov y Sergej Nikolaevich Shestov

The development of countries, societies, and human civilization as a whole, due to the rather low knowledge and ability of humanity to manage several global processes critical for its existence, encounters many difficulties associated with socio-economic, environmental and other crises. One can simply point to the protracted economic crisis that began in 2008, as well as the 2020 crisis that joined in due to the socio-economic, political, and other consequences of the coronavirus (COVID-2019) pandemic.

A specific set of objectives considered in the development, implementation, and subsequent modification of the national healthcare model is determined by the government's policy in the field of healthcare, as well as in the social sphere.

During periods of crisis, solving several urgent tasks for the state and society, pandemics, etc., the sustainability of national healthcare systems, their ability to solve both current (ordinary) and extraordinary tasks (due to martial law, state of emergency, prevention or elimination of natural or man-made emergencies) become the priority. In this regard, in this study, along with the general characteristics of the existing healthcare models, we attempt to consider their potential (embedded in the model itself) and real possibilities for reaching the objectives planned for them by the political administration of the state and society.

\section{Methods}

In our study, we used the following methods: a comparative analysis of Russian and foreign healthcare models, synthesis, structural-functional and statistical analysis, as well as the empirical cognition method.

\section{Results}

Speaking about the healthcare development strategy, one should pay attention to the need to switch to the principles of the four Ps healthcare (predictive, preventive, personalized, and participatory) (Drucker and Krapfenbauer, 2013; Gefenas et al., 2011; Scott, 2011). This kind of transition is impossible without the introduction of medical, genetic, informational, managerial, and other technologies into the industry. The introduction of new technologies for financing the industry (Sokolov and Kostyrin, 2018) is also a possibility to stimulate the main subjects and participants of legal relations in the healthcare sector to increase various types of efficiency, as well as to provide better healthcare. In this regard, the issues of innovative development of national healthcare systems are gaining importance. 
For example, in Decree No. 254 of the President of the Russian Federation "On the strategy for the development of healthcare in the Russian Federation for the period until 2025" dated June 6, 2019, the development of new medical technologies and their implementation in the healthcare system and the widespread introduction of the directed innovative development mechanism for the industry are called the priority areas in healthcare development.

During periods of various crises and especially world pandemics, the task of ensuring the accessibility of a limited range of medical services critical from the standpoint of preserving the citizens' life and health to a wide range of people, preventing and treating socially significant diseases and diseases that are dangerous to others become one of the most urgent. Thus, in connection with the ongoing global spread, the threat of the import and spread of a new coronavirus infection (COVID-2019) in Russia, it was required to add the coronavirus infection to the list of diseases that are dangerous to others (Postanovlenie Pravitelstva, 2020) and reassign many medical organizations and other organizational measures (Prikaz Ministerstva zdravookhraneniya, 2020). The problems of technological lag, which should be overcome shortly, were also revealed.

Politicians and authorities in many countries see the achievement of the main healthcare goals differently, which is manifested in their choice of one of the basic healthcare models with possible national variations of its blocks and subsystems.

In the specialized literature, one can find various classifications of national healthcare models. The most accessible, understandable, and integrative, in our opinion, is the division into the following models: the non-state (private) healthcare model, the health insurance model with various options for organizing medical care (services) and financing channels (Medik, 2018; Shcherbakova, 2015), state-funded healthcare, as well as the model based on funded medical bills.

Many of these models have repeatedly been modified since the time of their development and implementation, but in general, they have retained their inherent features to the present.

In healthcare models, keeping in mind national characteristics, such factors are considered and can be individualized as the role of the state in regulating relations in medicine and healthcare; state guarantees in the field of health; the mechanism for financing the industry, medical care and services; the main agents of the industry (business entities, doctors) and their characteristics; the availability and quality of medical care and services provided to the population (both by categories of citizens and by the types of assistance and services provided); provision with medicines, medical products, and other means of medical use; economic (Isalova and Tasueva, 

Alexandre Anatolievich Mokhov, Yury Alexandrovich Svirin, Vladimir Aleksandrovich Gureev, Vladimir Viktorovich Kulakov y Sergej Nikolaevich Shestov

2008), social, and medical efficiency; susceptibility to the introduction and widespread use of innovations (medical, genetic, informational, managerial, etc.) (Birkun, 2013).

The non-state (private) healthcare model is based entirely or mainly on the laws of a market economy. In this system, the role of the state is minimal, reducible to the implementation of individual programs or actions financed from the budget, but using the existing private infrastructure (private practitioners and medical organizations). Such a healthcare model has historically been considered one of the oldest ones.

In Russia, a private healthcare model had also developed for many centuries. The development of the elements of the state healthcare model begins with the era of reforms started by Peter I, who organized the medical support of the army and navy. Later, serious attempts to provide the general population of the country with certain types of medical services at the expense of the state and (or) business were made as early as the 19th century, which led to the development of medicine in rural districts and urban areas. However, until the 1920s, the country was dominated by the private sector (represented by private doctors for wealthy citizens and by healers, herbalists, and midwives for the bulk of the Russian population).

The formation and wide dissemination of the non-state healthcare model were facilitated by some historical, national, cultural, and other prerequisites that still exist in some countries of the world (for example, in some African and Asian countries). Of great importance is the lack of constitutional and/or other national laws that impose obligations on states in the field of healthcare.

The advantages of a private healthcare model are as follows: minimal government intervention in the provision of medical services; consolidation of the most general rules and norms of the functioning of the medical services market; as a rule, average economic efficiency (depends on the competition in the national market); free choice of doctor by the patient; high autonomy of the doctor; a large selection of medicines and medical products (usually imported).

However, the private model also has drawbacks: the limited availability of medical services for some groups of the population (the number of such groups and their representation is determined by the particular state, its economy, employment structure, etc.); limited possibilities of the state regarding the implementation of healthcare and social policies (the number of possible agents for implementing the policy is low); the presence of restrictions on the introduction of innovations in the industry (due to restrictions on the solvency of the population and the lack of state support for the introduction of new technologies). 

low.

Given the foregoing, the social efficiency of the private model is quite

Its medical efficacy, in general, can be described as average. However, failure may occur in certain areas. The issue of infant and maternal mortality is still quite acute in these countries. For example, the infant mortality rate in Afghanistan in 2018 was 50.82 (per 1,00o births), while in Finland this number is as low as 1.7.

In the context of socio-economic crises, pandemics, and other emergencies, the private healthcare model is under great stress. A significant part of the population does not have the funds to carry out the necessary diagnostic tests, examinations, etc., or to purchase means for emergency disease prevention. Allocation of money for certain medical, sanitary, and other events by the state is possible, but it also often turns out to be ineffective due to the limited resources of the industry itself, represented by private medical organizations and (or) private practitioners, and sometimes due to the inflation of prices for medical services. Another problem is the virtually uncontrolled spread of infectious diseases from the territories of such countries, which requires additional measures by governments and officials of neighboring states to ensure biological safety and sanitary and epidemiological well-being.

The situation is aggravated if the crisis becomes protracted. Governments of countries with such healthcare models seek help from other countries, international agencies, and other organizations. For example, in 2014 alone, the World Health Organization (WHO), to prevent the further spread of Ebola, which had spread across nine African countries, deployed 77 field sites and 26 mobile laboratories, sent more than 710 WHO employees and 2013 technical experts, and assisted in the construction of five Ebola treatment units (Rol VOZ v borbe s epidemiei Eboly v Zapadnoi Afrike, 2015).

The existing healthcare system in the US is close to a private healthcare model. It combines various financing mechanisms, such as voluntary medical insurance, compulsory medical insurance, payment through personal medical savings accounts, etc. Most often, employers act as insurers, less often patients acquire insurance at their own expense. During the Obama administration, insurance was actively introduced for the most vulnerable, underprivileged groups of the population. Programs for the health insurance policy acquisition at the expense of the state budget were introduced.

Despite the non-governmental nature of US healthcare, government funding for the industry in some areas remains high.

Significant sustainability challenges for the US healthcare industry have been revealed by the coronavirus pandemic. The healthcare system 
Alexandre Anatolievich Mokhov, Yury Alexandrovich Svirin, Vladimir Aleksandrovich Gureev, Vladimir Viktorovich Kulakov y Sergej Nikolaevich Shestov

turned out to be limited in mobility and showed low medical and social effectiveness. Questions about the cost-effectiveness of American healthcare have been posed before: despite huge costs (about 15-17\% of the country's GDP), the US healthcare industry is not a leader in virtually any of the indicators that characterize national healthcare. An exception is the industry's susceptibility to innovation (Global Innovation Index, 2017; Global Innovation Index, 2018; Global Innovation Index, 2019). The US is one of the countries with the largest number of registered innovative drugs, medical devices, and other medical facilities. The fact is that most of the biotechnology companies in the world are registered in the US. For them, the American market is the first and one of the most important ones (Sidorov, 2016).

It should be noted that despite the greatest scientific and innovative potential in medicine and pharmaceuticals, in recent years, they have been talking more and more actively about the "subsidence" of innovations, the insufficient susceptibility of American hospitals to new technologies, the very high cost of innovations for the industry, and other negative trends (Kristensen et al, 2011).

At the end of the 19th and the beginning of the 2oth century, the nongovernmental healthcare model was gradually replaced by other types of healthcare systems under the influence of serious economic, social, and political changes.

In many European countries, health insurance is being introduced (with variations in the degree of coverage of the population). Separate healthcare tasks, first of all, those related to public health, are solved at the expense of the budget. The formed model is beginning to be called the "Bismarck system". Otto von Bismarck wrote: "The state should take care of its subjects in need of help more than it has done so far. This is not only a matter of commitment to humanity and Christian virtues, which should be permeated by state institutions but also the task of a policy striving to strengthen the state, for its purpose is to inspire the poor classes of the population, who, at the same time, are the most numerous and least wealthy, that the state is not only a necessary institution but also a benefactor (Bismarck, 19241935).

The state creates conditions for the implementation of medical activities and guarantees a certain basic minimum of medical care (services) for the population. The market is formed based on various subjects of ownership, legal form, and other characteristics. The industry is financed from several sources (channels): insurance contributions (fees) of obligated entities (employers, individuals), budget funds, and other sources. Money follows the patient here. Financing, therefore, is tied to the number of patients served. The average cost of healthcare amounts to about $7-10 \%$ of the country's GDP (Komissinskaya and Ovod, 2018). 
In "perfect" conditions, this results in the formation of a competitive environment, with a struggle for the patient, which helps to stabilize prices for services and increase their quality. There are prerequisites for ensuring sufficient industry efficiency in the main areas. In principle, this model accepts innovation quite well. At least at the initial stage of the functioning of the "Bismarck system" in Germany, France, and some other European countries, they were quite innovative. The rapid development of pharmaceuticals in these countries in the first half of the 2oth century testifies to this.

Doctors have sufficient autonomy in this system, uniting into professional communities (medical associations, etc.).

Currently, the system under consideration has accumulated some problems, in connection with which efforts are being made to modernize it.

One example of a well-functioning healthcare system is healthcare in Israel. It is based on the "basket of health", a guaranteed set of medical services. They are provided by the state (public) medical organizations. Other services are provided under voluntary health insurance contracts or from other sources not prohibited by law.

The health insurance model works well or satisfactorily in normal, "standard" economic, social, and political conditions. However, during periods of crisis, the load on the industry increases, and available funds and reserves, as a rule, quickly exhaust themselves.

The formation of the state-financed healthcare model is associated with the name of N.A. Semashko, one of the prominent organizers of the USSR healthcare system.

This healthcare model was oriented towards solving the complex tasks of the young socialist state. It was characterized by a high level of centralization of management and logistics; the monopoly of the state represented by the medical organizations created by it on the provision of medical care; universality and accessibility of medical care; availability of standards for the main activities, operations, etc. (personnel, wages, medicine provision). The basic principle of financing is "money goes towards the patient". The state creates, purchases, and provides, and the final consumer (represented by the patient) and the intermediate (represented by the medical organization), consume the services.

The doctor in this system is an employee; their autonomy is limited. Professional communities (mainly based on belonging to medical or other specialties) solve a narrow range of problems.

In addition to the USSR, this healthcare model was introduced in several Eastern European countries, as well as in other states of the socialist bloc. In literature, it is sometimes also called the socialist system (Field, 

Alexandre Anatolievich Mokhov, Yury Alexandrovich Svirin, Vladimir Aleksandrovich Gureev, Vladimir Viktorovich Kulakov y Sergej Nikolaevich Shestov

1980). Some of its elements were borrowed by countries not included in the socialist camp.

In general, it has proven itself well, has shown stability and the ability to solve the main tasks in difficult years for the country (pre-war, wartime, and post-war). There was also a certain "reserve" of industry capacities (bed capacity, personnel, material reserves), which allowed it to cope with emergencies that had repeatedly arisen over the history of its existence. It was also quite economical. On average, the state spent about $3.5 \%$ of GDP on healthcare. This was not enough, but the industry provided the guaranteed volume of medical care of medium quality.

At the same time, it had many shortcomings: low incentives to increase its effectiveness (primarily economic), insufficiently high innovative potential, the difficulty of making managerial decisions (developed bureaucratic apparatus); poor equipment (lack of diagnostic tools, medical equipment, etc.).

It is also important to note that the party and state nomenclature was not personally interested in the development of the most advanced medicine since its medical and drug support was provided by the forces of the 4th Main Directorate under the USSR Ministry of Health.

With the collapse of the USSR, this model ceased to exist. Currently, its elements are used in some countries of the former socialist camp.

Another state healthcare model appeared historically a little later in the UK. On behalf of W. Churchill, U. Beveridge developed a program for the post-war development of the country, in which a significant place was given to the creation of the National Health Service (NHS). It provided for financing from the state budget through special taxes. In this model, the state became both the main supplier and the main buyer of medical care. However, there was an interesting feature: the money did not just go to the service providers according to the established standard but followed the patient, which created incentives for general practitioners to work better, attracting patients. This is similar to the health insurance model.

This model solved the problems of access to medical care, provided an acceptable level of quality of the services provided, and played a positive role at a certain historical period. However, the availability of assistance quickly led to an increase in the volume of services rendered (unjustified calls, appointments), and, ultimately, to a shortage of funds for the industry. The authorities were gradually forced to introduce various restrictions aimed at lowering costs (setting limits, creating special funds, forcing doctors to prescribe non-original medicines (generics, copies), etc.).

The innovative potential of the industry can be characterized as average. 
From the standpoint of solving the tasks assigned to the industry in crises, emergencies, and other extraordinary situations, such a system as a whole is stable, but inferior in effectiveness to the Semashko system.

Since the 1980s, first in Singapore and later in South Africa, partly in China and some other countries, a system of medical savings accounts has been introduced. It was based on a completely new approach for the industry, the creation of a "responsible patient" with motivation for the economical consumption of industry resources. It should be noted right away: the issue of the economy in the industry has been resolved. Singapore spends the least on healthcare but is one of the leaders in industry efficiency worldwide (Reiting stran mira po effektivnosti sistem zdravookhraneniya, 2018). In this model, money goes with the patient (Grishin, 2008), is spent personally by them, and not by anyone else. This model can significantly reduce operating costs and eliminate corruption in the industry.

The sources of funds transferred to personal savings accounts for each category of citizens are company funds; federal budget funds (military personnel, public servants, etc.); personal funds, savings (for individual entrepreneurs, foreign citizens, etc.).

It should be noted that the state continues to finance certain types of medical care (primarily emergency) in the framework of the current model. There is also a system for subsidizing certain types of medical care (in particular, for patients with diabetes, heart and blood vessel diseases, and some others).

Singapore is increasingly compared to Boston for the presence of worldclass hospitals in it, the active investment of both public and private funds in medical, biomedical, pharmaceutical, and other startups. It also has world-class pharmaceutical and medical clusters.

The stability of the new system has not been seriously tested to date, but the data on the spread of coronavirus infection (COVID-2019) in Singapore available at the time of preparation of this work let us conclude that the country successfully coped with the existing risks and threats. One must pay attention to the presence in the country as a whole of a rather rigid system of organizational and legal means to ensure biological safety.

Now we give a brief description of the current Russian healthcare model.

In Russia, with the adoption of the Law No. 1499-I of the Russian Federation "On Medical Insurance of Citizens in the Russian Federation" dated June 28, 1991, a combination of budget-financed and insurance-based models with multi-channel financing began to function. This document proclaimed the goal of medical insurance to guarantee citizens that they receive medical care from accumulated funds in case of an insurable event. 
Alexandre Anatolievich Mokhov, Yury Alexandrovich Svirin, Vladimir Aleksandrovich Gureev, Vladimir Viktorovich Kulakov y Sergej Nikolaevich Shestov

It is a modified Bismarck system with elements of the US system (in terms of the actual orientation of the industry towards obtaining funds through the provision of medical services on a fee basis not only in the private but also in the public health sector).

The system was based on the formula "money follows the patient", but it acquired distorted and even ugly forms. Insufficient financing of the industry, implementation of the tariff more than two times lower than the originally calculated one when implementing the system of compulsory medical insurance, led to the fact that at all stages of the movement of funds attempts are made for their misuse, withdrawal, delay in payment, etc. To this, we should add the intermediaries represented by insurance medical organizations, which do not provide insurance services but can use part of the system's funds. At the same time, this healthcare model did not become universal in Russia. Some population groups (such as military personnel, police officers, etc.) were excluded from it. The Soviet approach to the medical provision of senior officials of the country was also preserved (represented by the Main Medical Department of the Office of the President of the Russian Federation).

The Russian experience has shown that the current model is extremely inefficient, despite repeated attempts to reconfigure it, including at the legislative level.

Among the main problems of compulsory health insurance, as a rule, one can name low availability of medical care, increase in paid medical services, inefficiency in spending money, and control over the finances of the system (Bystrova, 2012).

Usually, the financing of medical care comes not only from the funds of the employer or the state but also from the income of the insured person.

The Russian healthcare model makes it possible, regardless of the number of contributions of a particular person, to apply for free medical care in the prescribed manner. However, this medical care will be minimal and does not guarantee a high quality of life and health. Therefore, the effectiveness of Russian healthcare is rated as extremely low. In recent years, Russia has been among the five worst countries in the world in terms of the effectiveness of healthcare systems.

Russian medical industry cannot boast of its innovations. For many years, science has been greatly underfunded, and without it, it is difficult to hope for new technologies. Besides, the complex relationship between science and medical practice, the lack of transparent and effective means, including legal ones, of promoting innovative products, also worsens innovative activity in the industry. The system does not contribute to the introduction of innovations since it is not oriented towards increasing its effectiveness. The "science-production-market-consumer" innovation chain does not exist (Ivanov, 2017). 
Low population density, low incomes, underdeveloped infrastructure, networks of medical organizations, and other objective factors (Korablev, 2012) also do not allow us to hope for high industry efficiency in the coming years.

The coronavirus infection (COVID-2019) was a positive moment for Russian healthcare, putting it to the test. The state had to mobilize all the resources of the industry (the budget component) and, in the period of high preparedness for the introduction of an emergency in connection with the pandemic, try to influence the current situation through previously developed administrative mechanisms. Part of the state medical healthcare organizations began to function in the regime of the state model of a public health emergency.

In our opinion, the state should also admit its mistake of moving from the state healthcare model to the combination of budget-financed and insurance systems, since it did not consider the non-viability of this system in the long term. At the same time, it fixed this model at the highest level. According to Part 1 of Art. 41 of the Constitution of the Russian Federation, medical assistance in state and municipal healthcare institutions is provided to citizens free of charge from the budget, insurance contributions, and other income.

The insurance model is a model of the late 19th - early 20th century. It was developed and implemented in the time when the economy, society, social sphere, and technologies were completely different. Today, the world is on the verge of the fourth industrial revolution, the next change in technological mode, which can no longer be ignored by politicians, economists, lawyers, and legislators.

Regardless of the country and national characteristics of health insurance, this system is under serious pressure. It copes relatively well with the tasks assigned to it under the following conditions: a high number of people employed in the legal economy (which is typical for an industrial economy), a rather low and stable number of sick people (typical for young societies, with a small number of old people). Many modern economies are characterized by a rather low number of the full-time workforce, a high unemployment rate, a change in the structure of employment, an aging population, a large number of people with disabilities, and other categories of citizens who need protection.

Modern technologies contribute to the development of medicine. They open great opportunities for physicians and patients but are expensive for the healthcare system. Therefore, they are either not implemented on time or are implemented, but access to them (the "waiting list") becomes virtually impossible for most citizens entitled to appropriate assistance with the application of new technologies. 
Alexandre Anatolievich Mokhov, Yury Alexandrovich Svirin, Vladimir Aleksandrovich Gureev, Vladimir Viktorovich Kulakov y Sergej Nikolaevich Shestov

In connection with the problems in the industry as a whole, the solution of which is difficult in the given coordinate system (the current combination of budget-financed and insurance-based models, ineffective and inadequate to the needs of financing the industry with compulsory health insurance), attempts are being made to search for a new model.

Based on the foregoing, there are only two main options: a return to the state-financed healthcare model (through fixing a special tax), but with the introduction of corrective mechanisms in it, leveling its main disadvantages to one degree or another, or a transition to a model of personal medical savings accounts. It may also be proposed to discuss an innovative healthcare model that meets all modern requirements and is free from the known shortcomings of already tested models. However, so far, no such models have been submitted for discussion.

The transition to medical savings accounts looks like an evolution. According to the order of deductions made and their features (dividing by working and non-working patients, transfer of funds for the nonworking population to budgets of various levels, etc.), the model of medical savings accounts is generally similar to the Russian one, but there is also a fundamental difference. The funds go to medical savings accounts and not to the compulsory health insurance fund, where they are immediately depersonalized and later used in the current period to pay for medical assistance to someone.

At the level of the Constitution of the Russian Federation and federal laws, there are no significant obstacles to its implementation. The concept of insurance premium is not expressly enshrined in federal law. There is a long discussion in the literature on this topic, but regardless of it, for publiclaw insurance contributions, attention is focused on their commitment, focus (the formation of trust funds and other sources for targeted spending), goals (financial provision of public obligations).

The Tax Code of the Russian Federation classifies insurance premiums as direct federal taxes, namely, contributions payable by employers in connection with their payment of income (including wages; the "salary" tax). Only Federal Law No. 326-FZ "On Compulsory Medical Insurance in the Russian Federation" dated November 29, 2010, will have to lose force in connection with the adoption of a new Federal Law, such as "On Personal Medical Savings Accounts in the Russian Federation" (Mokhov, 2020).

At the same time, geographical, political, national, and other features, traditionally low financing of the healthcare industry (hopes for compulsory medical insurance as a tool to increase the financial sustainability of the industry for almost thirty years of history have not been met), as well as current challenges and threats (decrease in business activity, the growth of unemployment, environmental problems, the growth of natural and 
man-made emergencies, the threat of bioterrorism, etc.) are putting on the agenda the question of preparing for the introduction of a new state healthcare model.

The benefits of a state healthcare model are well known and may be attractive to politicians and legislators. Some of the shortcomings can be eliminated or leveled but for this, the issues aimed at ensuring the efficiency of the industry as a whole and the business entities and the development of its innovative potential will have to be resolved at the stage of preparation of such a model. This will allow for the timely implementation of the latest technologies in the industry (genetic, information, etc.).

\section{Conclusion}

As a result of the study, the following conclusions were made:

1) The insurance-based healthcare model has not paid off during the period of sharply increased workload in the spring of 2020. This model copes relatively well with the tasks assigned to it when the number of people employed in the economy is high and the number of sick people is rather low and stable. However, in the modern world, the aging of the population exceeds the number of births, which is why we see a rather low number of the permanently employed population, a high unemployment rate, a large number of disabled people, and other categories of citizens in need of protection.

2) The combination of budget-financed and insurance-based healthcare models existing in some countries is also ineffective. Therefore, it is necessary either to return to the state healthcare model (through fixing a special tax) or to switch to a model of personal medical savings accounts or an innovative healthcare model.

3) The study revealed two possible options for the development of a healthcare model with the highest efficiency of providing medical services to the population:

- Return to the state healthcare model (through fixing a special tax), but with the introduction of corrective mechanisms, leveling its main disadvantages to one degree or another.

- Transition to the model of personal medical savings accounts.

4) An important problem that is practically not solved under the conditions of compulsory medical insurance of the population is the lack of any motivation for citizens to have a healthy lifestyle and to preserve their health. Without its solution, the transition 


\footnotetext{
Alexandre Anatolievich Mokhov, Yury Alexandrovich Svirin, Vladimir Aleksandrovich Gureev, Vladimir Viktorovich Kulakov y Sergej Nikolaevich Shestov

from established curative medicine to preventive medicine becomes impossible.

5) Advantages of a private healthcare model are the following: minimal government intervention in the provision of medical services; consolidation of the most general rules and norms of the functioning of the medical services market; as a rule, average economic efficiency (depends on the competition in the national market); free choice of doctor by the patient; high autonomy of the will of the doctor; a large selection of medicines and medical products (usually imported). However, during the pandemic period, this healthcare model proved to be ineffective, as large segments of the population were left without medical care and contributed to the growth of the pandemic both within the country and abroad.

\section{Acknowledgment}

This article was prepared with the financial support of the Russian Foundation for Basic Research (RFBR) (project No. 18-29-14063).

\section{Bibliographic References}

SIDOROV, Aleksandr Arkadyevich. 2016. «Vydayushchiesya rezultaty deyatelnosti liderov mirovoi bioekonomiki. Outstanding performance of world bioeconomic leaders» In: Regionalnoe razvitie. Vol. 1, No. 10.

MOKHOV, Alexandr Anatolievich. 2020. «Meditsinskie nakopitelnye scheta: pravovoi vzglyad. Medical savings accounts: the legal perspective» In: Ekonomika i upravlenie: problemy, resheniya. Vol. 1, No. 2, pp. 12-15.

SHCHERBAKOVA, Anna Aleksandrovna. 2015. "Institutsionalnye aspekty innovatsionnogo razvitiya zdravookhraneniya. Institutional aspects of innovative healthcare development» In: Problemy razvitiya territorii. Vol. 4, No. 48.

DRUCKER, Elisabeth; KRAPFENBAUER, Kurt. 2013. «Pitfalls and limitations in translation from biomarker discovery to clinical utility in predictive and personalised medicine» In: EPMA Journal. Vol 4, No. 1, pp. 7-8.

GEFENAS, Eugenijus; CEKANAUSKAITE, Asta; TUZAITE, Egle; DRANSEIKA, Vilius; CHARACIEJUS, Dainius. 2011. «Does the «new philosophy» in 
predictive, preventive and personalised medicine require new ethics? « In: EPMA Journal. Vol. 2, No. 2, pp. 141-147.

SOKOLOV, Evgenii Vasilievich; KOSTYRIN, Evgenii Vechyaslavovich. 2018. Proryvnye tekhnologii finansirovaniya zdravookhraneniya, pensionnogo obespecheniya i ekonomiki Rossii. Breakthrough technologies for financing healthcare, pensions, and the economy in Russia. Nauchnaya biblioteka. Moscow, Russia.

GLOBAL INNOVATION INDEX. 2017. 2017. Available online. In: https://www. wipo.int/publications/ru/details.jsp?id=4193\&plang=EN . Consultation date: $15 / 10 / 2019$.

GLOBAL INNOVATION INDEX. 2018. 2018. Available online. In: https:// www.wipo.int/publications/ru/details.jsp?id=4330. Consultation date: 15/10/2019.

GLOBAL INNOVATION INDEX. 2019. 2019. Available online. In: https:// www.wipo.int/publications/ru/details.jsp?id=4434. Consultation date: $11 / 09 / 2019$

KOMISSINSKAYA, Irina Gennadyevna; OVOD, Alla Ivanovna. 2018. «Vliyanie finansirovaniya zdravookhraneniya na uroven smertnosti $\mathrm{v}$ stranakh Evropy. The impact of health financing on mortality in Europe» In: Azimut nauchnykh issledovanii: ekonomika i upravlenie. Vol. 7, No. 4, pp. 147-150.

KRISTENSEN, Kley; BEMER, Richard; KENADZHI, John. 2011. «Istselyat li sistemu zdravookhraneniya proyvnye innovatsii? Will the healthcare system heal proactive innovations?» In: Menedzher zdravookhraneniya. Vol. 5, pp. 52-58.

BYSTROVA, Kseniya Evgenyevna. 2012. «Sostoyanie i problemy finansirovaniya obyazatelnogo meditsinskogo strakhovaniya. Status and problems of financing compulsory health insurance» In: Izvestiya SanktPeterburgskogo universiteta ekonomiki i finansov. Vol. 5, pp. 57-60.

ISALOVA, M.N; TASUEVA, D.A. 2008. «Regionalnye problemy effektivnosti ekonomiki zdravookhraneniya. Regional problems of health economics efficiency» In: Regionalnye problemy preobrazovaniya ekonomiki. Vol. 2, pp. 170-175.

FIELD, Mark. 1980.»The Health Sistem and Polisy: a Contemporary American Dialectic» In: Social Science and Medicine. Vol. 14a No. 5, pp. 401.

BISMARCK, Otto von. 1924-1935. Die gesammelten Werke, 2 Aufl. Stollberg. Berlin, Germany. 
Alexandre Anatolievich Mokhov, Yury Alexandrovich Svirin, Vladimir Aleksandrovich Gureev, Vladimir Viktorovich Kulakov y Sergej Nikolaevich Shestov

POSTANOVLENIE PRAVITELSTVA RF NO. 66. 2020. «O vnesenii izmeneniya v perechen zabolevanii, predstavlyayushchikh opasnost dlya okruzhayushchikh». Decree No. 66 of the Government of the Russian Federation «On Amending the List of Diseases of Danger to Others». Available online. In : http://publication.pravo.gov.ru/Document/ View/0001202002030005. Consultation date: 15/10/2019.

PRIKAZ MINISTERSTVA ZDRAVOOKHRANENIYA RF NO. $198 \mathrm{~N}$. 2020. «O vremennom poryadke organizatsii raboty meditsinskikh organizatsii v tselyakh realizatsii mer po profilaktike i snizheniyu riskov rasprostraneniya novoi koronavirusnoi infektsii (COVID-2019)». Order No. $198 \mathrm{H}$ of the Ministry of Health of the Russian Federation «On the temporary procedure for organizing the work of medical organizations to implement measures to prevent and reduce the risks of the spread of a new coronavirus infection (COVID-2019)». Available online. In: http://publication.pravo.gov.ru/Document/View/oo01202003190038. Consultation date: 15/12/2019.

REITING STRAN MIRA PO EFFEKTIVNOSTI SISTEM ZDRAVOOKHRANENIYA. 2018. The ranking of countries of the world on the effectiveness of health systems. Sostavlen analitikami agentstva Bloomberg na osnovanii dannykh Vsemirnoi organizatsii zdravookhraneniya, Organizatsii Ob»edinennykh Natsii i Vsemirnogo banka (compiled by analysts at Bloomberg based on data from the World Health Organization, the United Nations, and the World Bank). Available online. In: https://nonews.co/directory/lists/countries/ health. Consultation date: 15/10/2019.

ROL VOZ V BORBE S EPIDEMIEI EBOLY V ZAPADNOI AFRIKE. 2015. The role of WHO in the fight against the Ebola epidemic in West Africa. Vsemirnaya organizatsiya zdravookhraneniya. World Health Organisation. Available online. In: https://www.who.int/csr/disease/ ebola/who-activities-report/ru/. Consultation date: 15/10/2019.

BIRKUN, Snezhana Igorivna. 2013. «Innovatsionnoe razvitie mirovykh rynkov zdravookhraneniya. Innovative development of global healthcare markets» In: Sovremennye nauchnye issledovaniya i innovatsii. Vol. 6, No. 11 .

SCOTT, Stuart. 2011. «Personalizing medicine with clinical pharmacogenetics» In: Genet. Med. Vol. 13, No. 13, pp. 987-995.

IVANOV, V.V. 2017. Vvedenie v innovatiku. Introduction to Innovation. RAN. Moscow, Russia. 
MEDIK, Valerii Alekseevich. 2018. Obshchestvennoe zdorove i zdravookhranenie: uchebnik. Public health and healthcare: a manual. GEOTAR-Media. Moscow, Russia.

GRISHIN, Viktor. 2008. «Meditsinskie nakopitelnye scheta mekhanizm effektivnogo upravleniya i finansirovaniya okhrany zdorovya grazhdan. Medical savings accounts mechanism for the effective management and financing of public health» In: Pravo i upravlenie. XXI vek. Vol. 2, No. 38 .

KORABLEV, Vladimir Nikolaevich. 2012. «Modernizatsiya zdravookhraneniya: vchera, segodnya, zavtra. Healthcare modernization: yesterday, today, tomorrow» In: Problemy standartizatsii v zdravookhranenii. Vol. 9, No. 10, p. 8.

PRESIDENTIAL DECREE OF THE RUSSIAN FEDERATION. 2019. Available online. In: https://cis-legislation.com/document.fwx?rgn=116205. Consultation date: 15/10/2019. 


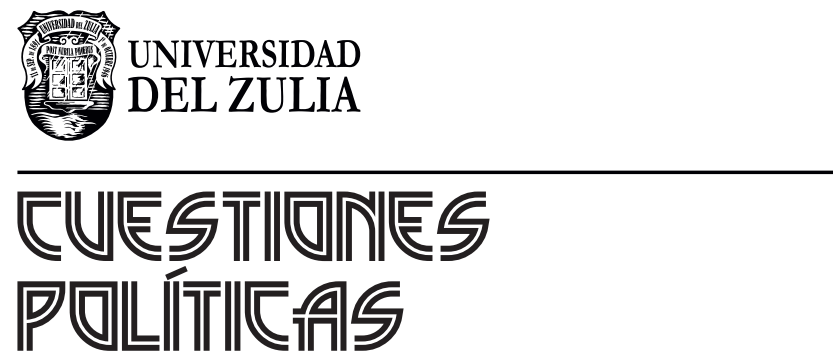

Vol.38 NEspecial

Esta revista fue editada en formato digital y publicada en octubre de 2020, por el Fondo Editorial Serbiluz, Universidad del Zulia. Maracaibo-Venezuela 